Vol. 5, No. 1, 2019

УДК 327.88:[070.42:323.266]

https://doi.org/10.23939/shv2019.01.007

\title{
INFORMATIONAL SPHERE - THE KEY FACTOR OF RUSSIAN HYBRID AGGRESSION AGAINST UKRAINE
}

\author{
Mykola Hetmanchuk \\ Lviv Polytechnic National University \\ ORCID: 0000-002-2627-8161 \\ hetmanchukm@ukr.net \\ Zoriana Zazuliak \\ Lviv Polytechnic National University \\ ORCID: 0000-0002-0098-9424 \\ zazuliak.zorian@gmail.com
}

(стаття надійшла до редколегї - 22.02.2019 р., прийнята до друку - 18.04.2019 р.)

(C) Гетьманчук М., Зазуляк 3., 2019

The features of the information component of the Russian-Ukrainian hybrid war are investigated. The main directions and tools of Russian destructive information activity aimed at Ukrainian society are determined. Communicative opportunities of parties in work with the mass audience are shown and characterized by obstacles on the way of counteraction to the Russian information aggression.

It is noted that today the problem of Russian propaganda became a necessity to deploy the fact that Ukrainian and Russians are brothers, as well as the formation of various interfaces concerning Ukrainians in Russian discourse.

The authors of the article emphasize that during the occupation of the Crimea and the Donbas, Russia uses a huge arsenal of justified propaganda technologies: "information blockade", "use of mediators", "anonymous authority", "feedback", "effect of presence", "stating the fact", "emotional resonance", "psychological shock", "ordinary story", "distraction", "technology of perspectives", and "false analogy".

It is proved that Russia's hybrid war against Ukraine has become a long-term factor influencing the national security of our country. In order to withstand this influence, a transparent and effective concept of information security should be formulated; we should continue working on the termination of pro-Russian TV channels and radio, and control the release of printed anti-Ukrainian products; the Ukrainian media should promptly refute Russian false and discrediting information; highlight the work of state institutions in the most transparent manner; increase the media literacy of the Ukrainian population and establish active informational work in the occupied territories.

Key words: Russian-Ukrainian hybrid war, information war, Word of war, information technology.

\section{ІНФОРМАЦЙНА СФЕРА - КЛЮЧОВИЙ ФАКТОР ГІБРИДНОЇ АГРЕСІЇ РОСІЇ ПРОТИ УКРАЇНИ}

\author{
Микола Гетьманчук \\ Національний університет “Львівська політехніка” \\ ORCID: 0000-002-2627-8161 \\ hetmanchukm@ukr.net \\ Зоряна Зазуляк \\ Національний університет “Львівська політехніка" \\ ORCID: 0000-0002-0098-9424 \\ zazuliak.zorian@gmail.com
}

Досліджено особливості інформаційної складової російсько-української гібридної війни. Визначено основні напрями та інструменти російської деструктивної інформаційної діяльності, спрямованої на українське суспільство, охарактеризовано перешкоди на шляху протидії російській інформаційній агресії. 
Зазначено, що сьогодні проблемою для російської пропаганди стала необхідність розвінчати тези про українців як про братній народ, а також сформулювати різні інтерпретації походження українців у російському дискурсі.

Доведено, що гібридна війна Росії проти України стала довгостроковим чинником впливу на національну безпеку нашої держави. Для того, щоб протистояти цьому впливові, потрібно визначити прозору та ефективну концепцію інформаційної безпеки; продовжити роботу щодо припинення діяльності проросійських телеканалів та радіо, виходу друкованої антиукраїнської продукції; українським ЗМІ оперативно спростовувати російську неправдиву інформацію; в максимально прозорому режимі висвітлювати роботу державних інституцій; підвищувати медіа грамотність українського населення та налагодити активну інформаційну роботу на окупованих територіях.

Ключові слова: російсько-украӥнська гібридна війна, інформаційна війна, смислова війна, інформаційні технологї̈.

The problem of "informational warfare", as well as the problem of "information weapon", was first explored in the early 80s. One of the first authors who in 1976 introduced the term "informational war" and formulated its main reasons is the American scholar Ron [Trebin 2005]. Today, most researchers argue that in modern terms there may be several types of informational wars: 1) cyberwar; 2) network warfare; 3) e-war; 4) psychological warfare; 5) radio electronic warfare [Mahda 2017]. The domestic military-theoretical opinion concerning the assessment of the RussianUkrainian war was reflected in the article of the Chairman of the Verkhovna Rada of Ukraine Parubiy, which appeared on the internet in August 2014, in particular, contains the following definition: "Ukraine is fighting, and the undeclared war, which is conducted by Russia against us, is defined as hybrid, nonlinear or war of controlled chaos. Such war combines military, informational, terrorist and other aggressive actions, which are coordinated from the unified center and are aimed at achieving a defined strategic goal. The purpose of this war is a complete subordination of Ukraine's towards Kremlin's expansionist plans" [Parubiy 2014].

Many Ukrainian experts researched the problem of the hybrid war, and its informational aspect in particular. It is important to note publications of Perepelytsia, Mahda, Rushchenko, Kopiyka, Potcheptsov, Horbulin and many others. In general, the "hybrid war" is traditionally understood as military actions, which are undeclared and during which the opposite side attacks the state structures, regular army and other major institutions of the enemy with the help of local rebels and separatists, supported by weapons and financial means from abroad and some internal structures (oligarchs, organized crime, cyber-crime, nationalist and other organizations). As practice proves, such wars are happening not only for certain territories, but also for influence on people's consciousness. This war is a form of military action involving the conflict of different composition, means, level and character of training of armed forces [Streltsov 2015]. It is primarily important to focus on the informational, psychological and ideological components of such a war. Pure military action of this war is hidden. Every single element of this war has its own influence and content, but very often they are strongly connected with each other. For example, if the informational war is aimed at information, then the psychological is addressed to emotions, but the purpose of these activities is one: to influence the mentality of a person (group of people), to provide the individual worldview with necessary content, which would be advantageous for the conflict initiator.

We consider the informational component the key one in the framework of the hybrid war. Its research is the main objective of our article. This work allows estimating it as not just a constituent, but a new form of such actions, namely - informational war. The purpose of the informational war is an immediate psychological influence on people to form their mentality in the desired direction [Senchenko 2014].

The analysis of the Russian -Ukrainian war events allows to discover certain laws of the hybrid war. At the theatre of military action Russia used the number of disruptive social technologies against Ukraine: 1) the technology of dividing Ukraine into the "people's republics"; 2) technology of creating criminal crowd; 3) the technology of rebellion and seizure of local power; 4) technology of "referendum"; 5) technology of "live shield", etc. All of them, according to the researchers, are characterized by certain characteristics: the similarity of goals; the standard of actions and means of achievement of goals; simultaneous realization of demarches in different cities of Ukraine; the similarity of external attributes, symbols, ideological and propaganda components of providing demarches [Ruschenko 2015]. After failing the attempts of destroying the Ukrainian state by military means and setbacks with the implementation of the so-called "Novorossia" project, the importance and role of the informational component of the hybrid War of Russia against Ukraine has considerably intensified.

According to the research of Ukrainian scholars, it is essential to highlight the main target audiences and relevant messages of Russian informational propaganda in the context of the hybrid war against Ukraine:

1) for the population of the Russian Federation: a) non-legitimacy of the current Ukrainian authorities (Euromaidan is a putsch organized by the Western special 
services, K.: Junta, NATO puppets, etc.) b) assertedly anti-Russian policy and radical nationalism of the current Ukrainian government; c) the repressions against the Russian-speaking population of Ukraine and the need to protect it by the Russian Federation;

2) for the population of the annexed and temporarily occupied territories of Ukraine: a) annexation of the Crimea is a forced reaction due to the threat to its population; Russia's actions and its army are aimed at protecting Russian-speaking citizens from the "K.: Junta" aggression; b) legitimacy of "referendums" concerning the annexation of Crimea by Russia and the declaration of "independence" of DPR and LPR; Antiterrorist operation in Eastern Ukraine, Joint Forces Operation is a civil war; c) The victims from the peaceful population are exclusively the results of actions of the armed forces of Ukraine;

3) for the population of Ukraine: a) the beginning of war, its victims and territorial losses is the responsibility of the current Ukrainian authorities; b) undermining the confidence of the citizens in Ukraine in the bodies of state power and the armed forces of Ukraine; agitation against mobilization to the Ukrainian army; c) dissemination of panic rumors among the civilians; support and popularization of pro-Russian and separatist movements and organizations; d) deterioration of socio-economic conditions, price growth, is a plan of the Ukrainian authorities aimed at the genocide of Ukrainians; e) propaganda of the ideas of great-state chauvinism, neo-Nazism and antisemitism; f) spreading of the ideologeme of "Russian world" ("ruskiy mir"); g) falsification of history in order to deny the existence of a separate Ukrainian nation; $h$ ) restoration of imperial and Soviet ideological stereotypes; s) incitement to the forcible overthrow of power ("appeals to the third Maidan") etc.;

4) for the population of other countries and the world community: a) accusing Ukraine in resolving the "civil war" and "genocide of the own people"; b) the image of Ukraine as an insolvent illegitimate state, unable to carry out its internal and external obligations and close to disintegration; c) accusing Ukraine in fascism, radical nationalism, extremism and mass violations of human rights; d) support of pro-Russian, extreme right and extreme left political parties, movements and organizations; e) appeals to the transformation of an existing world order, the division of the territory of Ukraine (and even the whole world) between the strongest states, the division between them the [Kopiyka 2017].

It should be noted that the informational expansion of Russia is based on the old meanings, familiar for the audience, on the activation and maintenance of the Soviet mental structures. Russian media are holding these structures to support the virtual dependence of people from the state. In their activities Russian informational operations against Ukraine most often use the following methods: 1) the fabrication of false information and misrepresentation; 2) technologies of deception (publication and reproduction of fake photos and videos, which were originally made under different conditions and pretend to be the testimony of "war crimes" of the Ukrainian army against the peaceful population); 3) glorifying the leadership of the Russian Federation and the Russian military power; 4) the constant use of the thesis of the Russian president V. Putin that the disintegration of the Soviet Union is "a geopolitical catastrophe of the twentieth century"; 5) continuous heroization of both the Soviet Army and the modern Russian military; 6) active use of the thesis concerning the nationalist and "fascist" Ukrainian society (which quite effectively influences the Western audience); 7) emphasis on the fact that the actions of the Ukrainian army in the Donbas area primarily cause children deaths, and this has a significant influence on any audience.

Russia's relevant government structures successfully carry out informational policies through three federal television channels. Taking into account an international audience, the leading channel is the TV channel "Russia Today", founded in 2005. It is broadcasted 24 hours a day in more than 100 countries of the world. The role of television as one of the most powerful instrument of Russia's informational influence on Ukraine and the world community remains more important than the role of the Internet. The presenter of the leading talk show on the first TV channel P. Tolstoy and the general director of "Russia Today" Kiselev, which are broadcasted in many foreign languages - are the two key Kremlin propagandists. Only financing of Kiselev, which is provided personally by President V. Putin, reaches up to $300 \mathrm{mln}$. US \$ per year. According to the "Ukrainska Pravda", in 2014 Russia spent $721 \mathrm{mln}$. US \$ for propaganda only on national TV channels in Russia. This number should also include $202 \mathrm{mln}$. dollars allocated to other channels such as NTV or first channel, as well as $86.7 \mathrm{mln}$. US \$ for RIA Novosti and $396 \mathrm{mln}$. US \$ for editing the programs in English, Arabic and Spanish [Hetmanchuk 2017].

Speaking of the high efficiency of Russian propaganda, it is worth paying attention to the extremely high level of cynicism, which dominates among employees of Russian TV channels, which produce the major part of propaganda content. Former members of the Russian Federal media noted that those who had some kind of moral principles, left their jobs at Russian television back in 2014 [The World Hybrid War 2017]. For example, every Sunday 10 million of Russians are watching D. Kiselev's show, and $10 \%$ of the nation 
considers him as the greatest intellectual authority in Russia. He scares the Russian population with the revival of Ukrainian nationalists, Banderovtsi, neo-Nazis, creates the image of Russia as a fortress surrounded by NATO forces and even threatens the U.S. with nuclear weapons [Arzhakovskyi 2015]. The informational channels of the Russian Orthodox Church remain particularly devoted to the Kremlin propaganda. It should be noted that the basis of the Russian unpredictability on the informational front is the neglection of the norms of ethics, logics, and sometimes common sense, which prevents any dialogue, and the absence of an answer is demonstrated by the Russian media as a victory [Chernenko $\mathrm{n} / \mathrm{d}$.].

After the presidential elections of Ukraine, the idea of P. Poroshenko's legitimacy gradually disappeared from Russian propaganda without any explanation. Now all the emphasis is on the correctness of the actions of those who are fighting on the side of the pro-Russian forces in Donbass. The negative has now moved to the Ukrainian military involved in the anti-terrorist operation. Even the term "karateli" was involved, borrowed from the days of World War II. When it comes to Crimea, Russian propaganda pays the main attention to the legitimization of the new powers of Crimea and the referendum on the entry of the Crimea to the Russian Federation. Russia as much as possible uses both former Soviet and pre-revolutionary symbolism, applies repressions against Ukrainians and Crimean Tatars. The authorities of the occupied Crimea almost eliminated the freedom of speech, even legally excluded the opportunity of any media to work on the peninsula, except proRussian ones. Therefore, one of the priority tasks of the implementation of the informational policy on the territory of Crimea is the speedy introduction of regular 24-hour TV and radio broadcasting. For this purpose it is necessary to: 1) actualize the Crimean problem, which somewhat went to the second plan compared to the events in the Donbass area; 2) inform the Crimeans about the real rather than the imaginary state of Russia in economic, social and other spheres; 3) segment the content not only on a regional level, but also on the intraregional; 4) emphasize on the problems of Crimeans from the position of care about the citizens in the occupied territories; 5) provide the necessary presence of the Crimean topic on the Ukrainian national channels, as well as in the Southern regions of Ukraine [Horbulin 2015].

The hybrid confrontation has brought a paradoxical outcome: the Russian communicative and propaganda campaign was so aggressive, that it turned away the Ukrainian population, which had an opportunity to capture obvious untrue deviations. This in particular, as well as the realities of the first months of Russian-Ukrainian military confrontation (the helplessness of Ukrainian military or those who led them, the strange inability of Ukrainian television to divert the open lies from Russian TV channels) had an inverse action - the process of formation of the Ukrainian political nation has started. Not only Ukrainians, but also Russians and representatives of other national minorities have gone to protect Ukraine's independence. Thus, for the Russians this military campaign influenced the raise in Putin's rating, and at the same time for Ukrainians in a strange way it worked on the contrary: the fall of Putin's rating and raising the feeling of their own national dignity. Usage of all the notions, by which Russian television describes the situation in Ukraine ("fascists", "Banderovtsi", "neo-Nazis", "Hunta", "illegitimate government"), on the one hand, was perceived with confidence by the greater part of the population of Russia, but completely undermined the confidence among the population of Ukraine, because it completely discorded with Ukrainian realities.

One of the consequences of the hybrid war was the activation of if not imperial, but quasi-imperial TV and radio broadcasting in Russia, as it is based on the expert environment that provides support for war. On the contrary, a broad anti-imperial TV-broadcasting was activated by the public society in Ukraine. The former USSR can only be determined as an empire, but the departure from the Soviet past, namely the prohibition in Ukraine of Russian informational and virtual products (not only in Ukraine, but also in Lithuania, Latvia, Moldova, Estonia, Georgia) - is a process of the direct farewell to the Empire. Before the beginning of military actions in Ukraine, Ukrainian society mainly consumed the Russian informational and virtual products. It formed the relevant model of the world for Ukrainians. The dissolution with this Russian model together with the absence of adequate own one have certain negative consequences, but Ukraine had to experience this process sooner or later. Ukraine is obliged now to actively invest in the creation of its own informational product, which will meet new requirements. It should be: a) intellectual; b) diverse; c) spread our own model of the world; d) answers to our own problems, not problems of other peoples [Potcheptsov 2015].

The practice of informational warfare showed that the success of the Russian TV channels has reached the maximum. The endorsement of $\mathrm{V}$. Putin reached the limiting heights. But the impact of Russian propaganda on the Ukrainian audience is minimal, since Russia chose to feature key objects of its description of the RussianUkrainian war events with the formalized means and periods of informational submission: 1) during the World War II ("Banderovtsi", "fascists", "karateli", "punitive troops") or its echo in the present ("Neo-Nazis"); 2) Soviet times ("Reunion of Crimea", "Crimea is ours"); 3) reflecting the "legality" of the Donetsk and Luhansk "protesters" against the K.: authorities ("People's 
mayor", "People's governor", "national referendum"); 4) showed the illegality of the K.: authorities ("nonlegitimate authorities", "self-proclaimed leaders", "Hunta"). For example, the mayor, elected to the square without any legal procedures, became "People's mayor", and this title provided his legitimacy. But the fact that this mayor is a Russian citizen did not matter.

At the initial stage of informational aggression in Ukraine also similar links were produced: 1) Russia's open intervention ("pro-Russian forces"); 2) "Terrorists", "mercenaries" (which allowed to include the global practice of combating terrorism, like it was made in Russia while fighting against Chechen separatism); 3) "bandits", "militants" to characterize the opponent (but it is limited to the understanding that among them is mobilized new "national power" of the citizens of Ukraine, who do not support Russian aggression). As we can see, in order to describe the key objects of the situation, propaganda uses not neutral, but negative terminology. That is, the negativity fights not against the situation itself, but against the symbolism existing in this model of the world. In this case, for several years both sides are describing both their military victories and the losses of the opponent. Under such conditions, and especially because of the prolonged nature of military action, among politicians and local populations are being activated primarily by the proponents of war, not peace supporters.

The informational war is aimed at turning the opponent into a real enemy, which causes hatred of the very fact of its existence. The main novelty of this informational war was the work with virtual objects, which almost fully lack of the reality and is used by Russian propaganda: 1) "Novorossia" - at least because historically the cities of Donetsk and Luhansk have never existed; 2) "Gentleman" - a man with a weapon in his hands can hardly be considered gentle, although others have to listen to him and perform his orders; 3) The conduct of the elections under the sight of weapon is unlikely to correspond with the notion of "electoral process". The virtual part of propaganda objects in this case requires to be filled with own symbols and history. In this context, researchers note that there is no Novorossia, it has no historical capital and borders. Every person outlines its abstract territory in its sole discretion, depending on the personal political conditions and individual fantasies [Kmet' 2014]. Russian political technologists had to make a lot of efforts to create a flag and other symbols of the so-called "Novorossia" [Kedrin n/d].

During the occupation of the Crimea and Donbass Russia used a considerable arsenal of other, more sophisticated propaganda technologies and techniques: 1) technology of "informational blockade" (formation of informational vacuum for the Ukrainian media), which essentially became an alternative of rigid censorship; 2) "use of mediators" technology (in different situations and for different social groups the mediators became informal leaders, political figures, representatives of religious concessions, etc. - for each category of the population their particular authority was chosen; 3) "anonymous authority" technology (the most effective method of misleading by quoting documents, delivering expert assessments, reports without naming the authors); 4) technology of "feedback" (Russian media has actively reported on mass actions of support of the Crimean separation, proclamation of LPD and DNR, which were actually artificially inspired); 5) "effect of presence" technology ("use of reports from the place of an event", which allows to distort the reality by specially assembled subjects); 6) technology of "stating the fact" (Russian media demonstrating the desired fact); 7) technology of "emotional resonance" (a way to create a wide audience with anti-Ukrainian moods by saturation of specific emotional details, which are better remembered); 8) technology of "psychological shock" (the Russian media "violent" actions of the Ukrainian military against pro-Russian citizens of Donbass); 9) technology of an "ordinary story" (used to adapt the person to the information of frankly negative content, to create an idea that it is not worth special attention); 10) technology of "distraction" (Russian media combine their propaganda plots with the entertainment component); 11) technology of "perspectives" (Russian media is giving the word only to the one side of the conflict, which ultimately creates a unilateral perspective); 12) technology of "false analogy" (extraction of events from the past to other, modern events that are not connected) [Horbulin 2015].

Russia's hybrid war against Ukraine became a long-term factor in influencing national security of our country. All the three its spheres - physical, informational and virtual - were not ready for this. But if the conclusions to the physical space are mainly done, then the two other lack them and need further work. For this purpose it is necessary: firstly, to formulate a transparent and effective concept of informational security, which will determine both strategic and tactical goals, ways of their achievement; secondly, to continue the work on cessation of the activity of pro-Russian TV channels and radio, output of printed anti-Ukrainian products; third, the Ukrainian media promptly deny Russian false and defamatory information; fourth, it is important in maximum transparent mode to illuminate the work of state institutions, which will quickly neutralize Russian propaganda attacks; fifth, increase the media literacy of the Ukrainian population; sixth, to develop measures on positioning of Ukraine in the international informational field, to establish active information work in occupied territories. 


\section{ЛІТЕРАТУРА}

Аржаковський, А. (2014). Розбрат України з Росією: стратегія виходу з піке. Погляд Свропи. Харків: Віват.

Гетьманчук, М. (2017). Гібридна війна Росії проти України: інформаційний аспект. Військово-науковий вісник, Випуск 27, 296-307.

Горбулін, В., Власюк О., Лібанова Е., Лященко О. (2015). Донбас і Крим: ціна повернення: монографія. Київ: НІСД.

Горбулін, В. (ред). (2017). Світова гібридна війна: український фронт (2017): монографія. - Харків: Фоліо.

Илларионов, А. (2014). К войне с Украиной Россия готовилась 11 лет, и она будет долгой. Отримано 3 http:// www.facenews.ua/news/2014/255780

Каліновська, О., Криштопа, О., Назаренко, Є., Трохимчук, В., Феденко, Д. (2015). Неоголошена війна. Невідомі факти і хроніки АТО. Харків: “Клуб сімейного дозвілля".

Кедрин, О. (н/д.). Флаги, гербы и лозунги: о PR проколах авторов "Новороссии". Отримано 3 sprotyv.info/ ru/news/3694-flagu-gerby-i-lozungu-o-prokolax-avtorovnovorossii.

Кметь, С. (2014). Что такое Новороссия и как с ней быть. Отримано 3 www.pravda.com.ua/rus/artiecles/2014/ 08/15/7034916

Копійка, В., Дорошко, М., Балюк, В. (2018). Гібридна війна Росії проти України після Революції гідності: монографія. Київ: Ніка-Центр.

Магда, С. (2017). Гібридна агресія Росії: уроки для Європи. Київ: КАЛАМАР.

Парубій, А. (2014). Війна Росії проти України і світу. Отримано з сайту Українська правда: www.pravda. com.ua/2014/08/7034046.

Почепцов, I. (2015). Сучасні інформаційні війни. Київ: Вид. дім “Києво-Могилянська академія".

Рущенко, I. (2015). Російсько-українська гібридна війна: погляд соціолога. Харків: ФОП Павленко О. I.

Сенченко, М. (2014). Латентна світова інформаційна війна. Київ: ФОП Стебеляк.

Стрельцов, Є. (2015). Сучасна війна у визначеннях Воєнної доктрини України. Національна безпека, № 36 , 12-18 вересня, 12

Требин, М. (2005). Войны XXI века. Москва: АСТ; Минск: Харвест.

Черненко, Т. (н/д.). Російське іномовлення як інструмент маніпулювання громадською думкою у трансатлантичному просторі. Отримано 3 http: // www.niss.gov.ua / articles/1834/

\section{REFERENCES}

Arzhakovsky, A. (2014). Dissention of Ukraine with Russia: exit strategy from the peak. View of Europe. [In Ukrainian]. Kharkiv: Vivat.

Chernenko, T. (n.d.) Russian Speaking Abrooad as a Tool for Manipulating Public Opinion in the Transatlantic Space. [In Ukrainian]. Retrieved from www.niss.gov.ua/ articles /1834/

Hetmanchuk, M. (2017). Russia's hybrid war against Ukraine: informational aspect. [In Ukrainian]. Military Scientific Herald, Issue 27, 296-307.

Horbulin, V., Vlasyuk, O., Libanova, E., Lyashenko, O. (2015). Donbass and Crimea: the price of return. [In Ukrainian]. Kyiv: NISS.

Horbulin, V. (ed.). (2017). The World Hybrid War: The Ukrainian Front. [In Ukrainian]. Kharkiv: Folio.

Illarionov, A. Russia was preparing for the war with Ukraine for 11 years, and it will be long. (2014). Retrieved from http: // www.facenews.ua/news/2014/255780.

Kalinovska, O., Kryshtopa, O., Nazarenko, E., Trochymchuk, V., Fedenko, D. (2015). Unwarranted War. Unknown facts and chronicles of ATO. [In Ukrainian] Kharkiv: "Family Leisure Club".

Kedrin, O. (n.d.). Flags, Coats of Arms and Slogans: about PR-punctures of the Authors of "Novorossiia". [In Russian]. Retrieved from sprotyv.info/en/news/3694-flagugerby-i-lozungu-o-prokolax-avtorov-novorossii.

Kmet', S. (2014). What is Novorossiia and How to Deal with It? [In Russian] Retrieved from www.pravda.com.ua/eng/ artiecles/2014/08/15/7034916

Kopiika, V., Doroshko, M., Balyuk, B. (2018). Russia's hybrid war against Ukraine after the Revolution of Dignity.[In Ukrainian]. Kyiv: Nika-Center.

Mahda, Ye. (2017). Hybrid aggression in Russia: lessons for Europe. [In Ukrainian] Kyiv: KALAMAR.

Parubiy, A. (2014). Russia's War against Ukraine and the World. [In Ukrainian]. Retrieved from www.pravda.com.ua/ 2014/08/7034046.

Potcheptsov, I. (2015). Modern Informational Wars. [In Ukrainian]. Kyiv: Publishing house "Kyiv-Mohyla Academy".

Ruschenko, I. (2015). Russian-Ukrainian Hybrid War: a Sociologist's View. [In Ukrainian]. Kharkiv: FOP Pavlenko O. I.

Senchenko, M. (2014). Latent World Information Warfare. [In Ukrainian] Kharkiv: FOP Stebeyak.

Streltsov, E. (2015). Modern War in definitions of the Military Doctrine of Ukraine. [In Ukrainian]. National security, No. 36, September 18, 12.

Trebin, M. (2005). Wars of the 21st Century. [In Russian]. Moscow: AST. Minsk: Harvest. 